\title{
PEMBIAYAAN USAHA MIKRO KECIL DAN MENENGAH (UMKM) SEBAGAI SOLUSI DALAM MENINGKATKAN PRODUKTIVITAS USAHA PADA UMKM KABUPATEN SORONG
}

\author{
Pitter Leiwakabessy $^{1 *}$ dan Fensca F. Lahallo ${ }^{2}$ \\ Fakultas Ekonomi dan Bisnis, Universitas Victory Sorong \\ pitter_leiwakabessy@yahoo.com \\ *ekalahallo120@gmail.com
}

\begin{abstract}
ABSTRAK
Permasalahan yang dihadapi UMKM cukup kompleks yaitu masih rendahnya produktivitas UMKM yang diakibatkan karena rendahnya kualitas sumber daya manusia UMKM khususnya dalam bidang manajemen, penguasaan teknologi, dan pemasaran. Selain itu, UMKM juga diperhadapkan pada terbatasnya akses kepada sumberdaya produktif, terutama terhadap permodalan, teknologi, informasi dan pasar. Kurangnya permodalan UMKM, oleh karena pada umumnya usaha kecil dan menengah merupakan usaha perorangan atau perusahaan yang sifatnya tertutup, yang mengandalkan pada modal dari pemilik yang jumlahnya sangat terbatas, sedangkan modal pinjaman dari bank atau lembaga keuangan lainnya sulit diperoleh, karena persyaratan secara administratif dan teknis yang diminta oleh bank tidak dapat dipenuhi. Kegiatan pengabdian masyarakat yang dilakukan untuk meningkatkan kesadaran para UMKM terkait dengan masalah pembiayaan dan memaksimalkan Produktifitas kegiatan UMKM dengan memanfaatkan peluang fasilitas kredit bank, bantuan koperasi, dan pihak ke 3 penyedia dana dalam membantu mengembangkan UMKM lebih meningkat serta memaksimalkan Kredit Usaha Kecil yang merupakan solusi dalam permasalahan pembiayaan UMKM untuk lebih berkembang dan Maju. Merespon persolaan UMKM dalam mempersiapkan perencanaan bisnis jangka pendek, penyusunan proposal pengembagan usaha serta fasilitas dan mediasi akses ke lembaga keuangan dan berbagai sumber pembiyaan serta manajemen keuangan yang dilakukan bersama pelaku UMKM pada saat pembimbingan teknis ini berjalan.
\end{abstract}

Kata kunci : UMKM, Pembiayaan

The problems faced by MSMEs are quite complex, namely the low productivity of MSMEs due to the low quality of MSME human resources, especially in the fields of management, technology mastery, and marketing. In addition, MSMEs are also faced with limited access to productive resources, especially towards capital, technology, information and markets. Lack of capital for MSMEs, because in general small and medium enterprises are private businesses or companies that are closed, which rely on capital from owners whose numbers are very limited, while loan capital from banks or other financial institutions is difficult to obtain, due to administrative and technical requirements requested by the bank cannot be fulfilled. Community service activities are carried out to increase the awareness of MSMEs related to financing problems and maximize the productivity of MSME activities by utilizing opportunities for bank credit facilities, cooperative assistance, and third parties providing funding in helping to develop more MSMEs and maximizing Small Business Loans 
which are solutions in the problem of financing MSMEs to be more developed and advanced. Responding to the SME business process in preparing short-term business planning, preparing proposals for developing businesses and facilities and mediating access to financial institutions and various sources of financing and financial management carried out with MSME actors when this technical guidance is running.

Keywords: MSMEs, Financing

\section{PENDAHULUAN}

Usaha Mikro, kecil dan menengah (UMKM) adalah salah satu bidang yang memberikan kontribusi yang segnifikan dalam memacu pertumbuhan ekonomi Indonesia. Hal ini dikarenakan daya serap UMKM terhadap tenaga kerja yang sangat besar dan dekat dengan rakyat kecil (Kuncoro, 2008, Sripo, 2010, dalam Jaidan, 2010 : 161). Usaha Mikro Kecil dan Menengah (UMKM) ini dianggap penyelamat perekonomian Indonesia di masa krisis pada periode 1992-2000 (Manurung, Adler Haymans. 2007 dalam Wahyuningsih 2009). UMKM mempunyai ciri khas yaitu modal yang kecil, resiko yang sedikit tinggi tetapi penerimaan juga tinggi, dan membawa kewirausahaan bagi pemiliknya.

Usaha Mikro Kecil dan Menengah (UMKM) memiliki potensi yang sangat besar dalam meningkatkan taraf hidup masyarakatnya. Hal ini ditunjukkan dari peranan UMKM dalam menyerap banyak tenaga kerja, pemerataan distribusi hasil-hasil pembangunan, dan penanggulangan kemiskinan. UMKM juga memegang peranan penting dalam ekspor nonmigas, yang pada tahun 1990 mencapai US\$ 1.031 juta atau menempati rangking kedua setelah ekspor dari kelompok aneka industri, dan adanya urgensi untuk struktur ekonomi yang berbentuk piramida, yang menunjukkan adanya ketimpangan yang lebar antara pemain kecil dan besar dalam ekonomika Indonesia (Kurniawan, 2009 dalam Jaidan, 2010 : 160 161).

Data statistik menunjukkan bahwa jumlah unit usaha kecil mikro dan menengah (UMKM) mendekati angka 99,98\% dari total unit usaha di Indonesia dengan kontribusi sebesar 56\% dari total PDB di Indonesia. Hal ini mencerminkan tingginya signifikansi peran UMKM bagi pemerataan ekonomi Indonesia, (Layyinaturrobaniyah \& Wa Ode Zusnita Muizu, 2017 : 91). Dibalik capaian-capaian yang telah diraih dan ditunjukkan oleh UMKM, teridentifikasi masih ditemukannya beragam persoalan yang paling mendasar dalam hal ini adalah terkait dengan masih rendahnya produktivitas UMKM. Rendahnya produktivitas ini disinyalir karena rendahnya kualitas sumber daya manusia UMKM khususnya dalam bidang 
manajemen, penguasaan teknologi, dan pemasaran. Selain rendahnya produktivitas, UMKM juga diperhadapkan pada terbatasnya akses kepada sumberdaya produktif, terutama terhadap permodalan, teknologi, informasi dan pasar.

Hingga saat ini, tidak sedikit pelaku usaha mikro yang mengeluhkan tentang perkembangan usahanya karena disebabkan kekurangan modal dalam bentuk uang. Begitu juga banyak kegiatan usaha mikro mengalami kegagalan atau bangkrut dikarenakan tidak mampu mengelola keuangan dengan baik. Pemahaman terhadap manajemen keuangan tidak hanya sekedar bagaimana cara mengelola uang kas, namun juga pada bagaimana cara mengelola keuangan untuk menghasilkan keuntungan. Meskipun terlihat mudah dan sangat sederhana, setiap pelaku usaha mikro kecil menengah (UMKM) penting untuk menerapkan pengelolaan keuangan yang baik. Minimal pelaku UMKM seharusnya mempunyai buku catatan kas masuk dan juga kas keluar. Sebab pada kenyataannya para pelaku UMKM lebih tertarik membahas ide dan inovasi bisnis, produksi dan target penjualan serta strategi pemasaran dibandingkan dengan berbicara manajemen keuangan. Para pelaku usaha mikro cenderung memandang pengelolaan keuangan sebagai kegiatan yang berjalan begitu saja tanpa perlu dilakukan pengendalian. Jika bisnis bagus maka keuangan bisnis juga akan sama bagusnya. Sementara pada kenyataannya, penghasilan yang diperoleh seringkali tidak berimbang dan sebanding dengan pengeluaran mereka, sehingga banyak pelaku usaha mikro yang kehabisan modal usaha tanpa mengetahui ke mana uang tersebut dibelanjakan.

Kondisi ini seringkali disebabkan karena keuangan usaha mikro yang dikelola tidak dipisahkan dengan keuangan keluarga. Oleh karena itu, dalam rangka menjaga keberlangsungan kegiatan usaha, maka diperlukan pengetahuan, ketarampilan dan sikap perilaku untuk mengelola seluruh aspek usaha dengan baik. Khusus di bidang keuangan diperlukan perhatian lebih khusus dan serius, karena keuangan merupakan jiwa dan darah seluruh kegiatan usaha. Sebagaimana pada umumnya, pengelolaan keuangan usaha juga meliputi seluruh aktivitas sejak perencanaan, pelaksanaan dan pengendalian. Salah satu upaya untuk bisa mengendalikan keuangan, diperlukan suatu keberanian untuk melakukan kontrol agar usaha tetap berjalan sementara kebutuhan keluarga juga terpenuhi. Untuk memudahkan pengawasan, pengusaha harus disiplin dan bijak dalam mendayagunakan uangnya, dan perlu dilakukan pencatatan untuk setiap penerimaan maupun pengeluaran. Karena dengan adanya catatan keuangan ini dapat diketahui semua rincian dan rangkuman penerimaan dan penggunaan uang. 
Selain itu, peran pemerintah dalam rangka mengembangkan Usaha Mikro, Kecil, dan Menengah (UMKM) memang sangat diperlukan, karena UMKM merupakan salah satu usaha yang potensial untuk meningkatkan perekonomian serta meningkatkan kesejahteraan masyarakat. Sehingga perlu adanya pemberdayaan dari segi sumber daya manusia, solusi masalah pembiayaan sampai pada pengadaan sarana dan prasarana. Selain itu, ada banyak manfaat dari adanya UMKM yaitu dapat menyerap banyak tenaga kerja serta mengurangi tingkat pengangguran. "Tujuan mulia yang ingin dicapai sektor publik, yaitu kesejahteraan sosial (social welfare) dengan sendirinya menuntut tata kelola pemerintahan yang baik (good governance). Saat ini tuntutan agar pemerintah mampu secepatnya merealisasikan pencapaian kesejahteraan sosial, semakin besar." (Keban, 2008, h.17-18 dalam Anggraeni,dkk). Dalam hal ini peran Dinas Koperasi dan UKM Kabupaten Sorong bersama PLUT - KUMKM Mandiri Kabupaten Sorong merupakan kepanjangan tangan dari Pemerintah Daerah untuk membantu mengatasi permasalahan yang terjadi dalam pengembangan UMKM dalam hal pembiayaan, produksi dan pengolahan, pemasaran, sumber daya manusia, serta desain dan teknologi.

\section{MASALAH}

Usaha Mikro Kecil dan Menengah (UMKM) memiliki potensi yang cukup besar untuk tumbuh kembang dalam meningkatkan taraf hidup masyarakat. Akan tetapi, teridentifikasi masih ditemukannya beragam persoalan yang dihadapi UMKM dan tentunya perlu mendapat perhatian dari semua pihak. Persoalan yang paling mendasar dalam hal ini adalah terkait dengan masih rendahnya produktivitas UMKM. Rendahnya produktivitas ini diakibatkan karena rendahnya kualitas sumber daya manusia UMKM khususnya dalam bidang manajemen, penguasaan teknologi, dan pemasaran. Selain itu, UMKM juga diperhadapkan pada terbatasnya akses kepada sumberdaya produktif, terutama terhadap permodalan, teknologi, informasi dan pasar. Hingga saat ini, tidak sedikit pelaku usaha mikro kecil dan menengah yang mengeluhkan tentang perkembangan usahanya karena disebabkan kekurangan modal dalam bentuk uang. Begitu juga banyak kegiatan usaha mikro kecil dan menengah mengalami kegagalan atau bangkrut dikarenakan tidak mampu mengelola keuangan dengan baik.

Dengan demikian, masalah dasar yang dihadapi UMKM yang dikutip dari Kurniawan (2009) dalam Jaidan (2010 : 161) adalah: (1) Kelemahan dalam memperoleh peluang pasar 
dan memperbesar pangsa pasar, (2) Kelemahan dalam struktur permodalan dan keterbatasan untuk memperoleh jalur terhadap sumber-sumber permodalan, (3) Kelemahan di bidang organisasi dan manajemen sumber daya manusia, (4) Keterbatasan jaringan usaha kerjasama antar pengusaha kecil (sistem informasi pemasaran), (5) Iklim usaha yang kurang kondusif, karena persaingan yang saling mematikan, dan (6) Pembinaan yang telah dilakukan masih kurang terpadu dan kurangnya kepercayaan serta kepedulian masyarakat terhadap usaha kecil.

\section{METODE}

Pelaksanaan kegiatan ini menggunakan metode pendidikan Masyarakat yakni metode yang digunakan untuk kegiatan-kegiatan, seperti a) pelatihan semacam in-house training; b) penyuluhan yang bertujuan meningkatkan pemahaman serta kesadaran, dan sebagainya. Dengan demikian kegiatan pengabdian masyarakat dilakukan dengan menggunakan metode sosialisasi ayau penyuluhan tentang masalah terkait pembiayaan UMKM dan solusinya.

\section{HASIL DAN PEMBAHASAN}

Adapun hasil dan pembahasan dari kegiatan pengabdian kepada masyarakat sebagai bentuk perwujudan dan implementasi Tri Dharma Perguruan Tinggi sebagai suatu solusi dalam meningkatkan produktivitas UMKM di Kabupaten Sorong dapat diuraikan sebagai berikut:

\section{Survei Pengenalan UMKM}

Survei awal lapangan UMKM pada salah satu Industri kecil yaitu Batu Bata milik Pak Wahono yang terletak di Jalan Tongkol Kelurahan Klamesen Distrik Mariat dan Penangkaran Ikan Lele Milik Pak Kasro di Daerah Klamalu Distrik Aimas Kabupaten Sorong pada tanggal 20 Juli 18. Tujuan dilakukannya kegiatan survei ini untuk mengetahui beberapa persoalan yang mengakibatkan UMKM sangat sulit berkembang dalam persaingan bisnis yang sama.
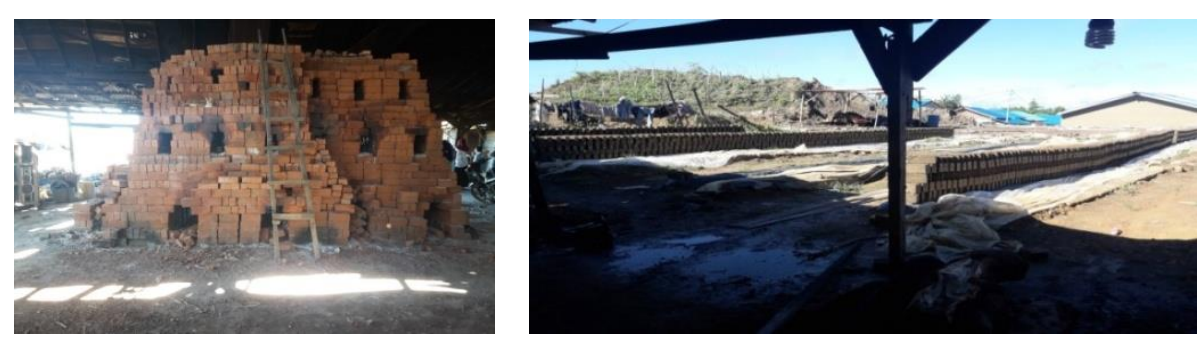

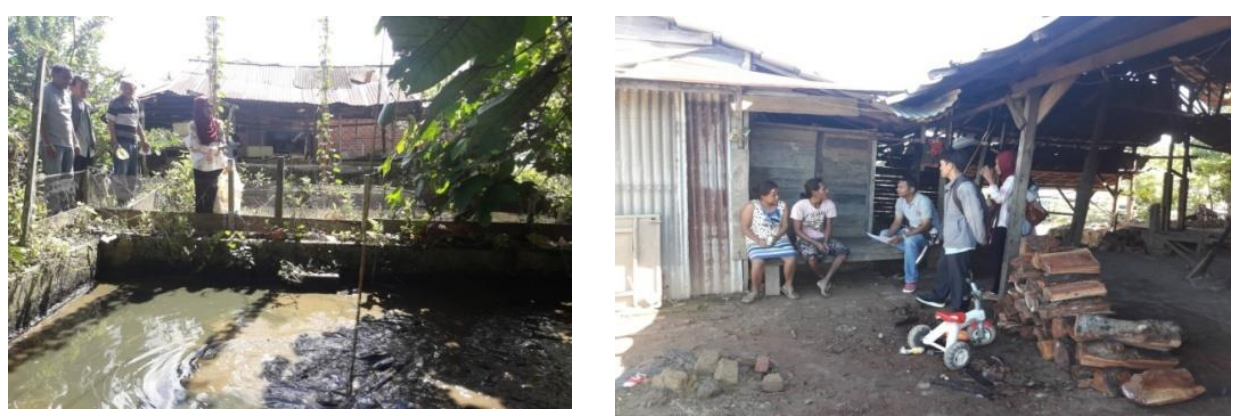

Gambar 2. Penangkaran Ikan Lele Milik Pak Kasro di Daerah Klamalu Distrik Aimas Kabupaten Sorong

Berdasarkan hasil survei, persoalan yang paling mendasar dalam hal ini adalah terkait dengan masih rendahnya produktivitas UMKM. Rendahnya produktivitas ini disinyalir karena rendahnya kualitas sumber daya manusia UMKM khususnya dalam bidang manajemen, penguasaan teknologi, dan pemasaran. Selain rendahnya produktivitas, UMKM juga diperhadapkan pada terbatasnya akses kepada sumberdaya produktif, terutama terhadap permodalan, teknologi, informasi dan pasar. Hingga saat ini, tidak sedikit pelaku usaha mikro, kecil dan menengah yang mengeluhkan tentang perkembangan usahanya karena disebabkan kekurangan modal dalam bentuk uang. Begitu juga banyak kegiatan usaha mikro, kecil dan menengah mengalami kegagalan atau bangkrut dikarenakan tidak mampu mengelola keuangan dengan baik.

Permodalan merupakan faktor utama yang diperlukan untuk mengembangkan suatu unit usaha. Kurangnya permodalan UMKM, oleh karena pada umumnya usaha kecil dan menengah merupakan usaha perorangan atau perusahaan yang sifatnya tertutup, yang mengandalkan pada modal dari pemilik yang jumlahnya sangat terbatas, sedangkan modal pinjaman dari bank atau lembaga keuangan lainnya sulit diperoleh, karena persyaratan secara administratif dan teknis yang diminta oleh bank tidak dapat dipenuhi.

Sebagian besar usaha kecil tumbuh secara tradisional dan merupakan usaha keluarga yang turun temurun. Keterbatasan sumber daya manusia usaha kecil baik dari segi pendidikan formal maupun pengetahuan dan keterampilannya sangat berpengaruh terhadap manajemen pengelolaan usahanya, sehingga usaha tersebut sulit untuk 
berkembang dengan optimal. Disamping itu, dengan keterbatasan SDM-nya, unit usaha tersebut relatif sulit untuk mengadopsi perkembangan teknologi baru untuk meningkatkan daya saing produk yang dihasilkannya.

Lemahnya jaringan usaha dan kemampuan penetrasi pasar usaha kecil yang pada umumnya merupakan unit usaha keluarga, mempunyai jaringan usaha yang sangat terbatas dan kemampuan penetrasi pasar yang rendah, oleh karena produk yang dihasilkan jumlahnya sangat terbatas dan mempunyai kualitas yang kurang kompetitif. Berbeda dengan usaha besar yang telah mempunyai jaringan yang sudah solid serta didukung dengan teknologi yang dapat menjangkau internasional dan promosi yang baik.

\section{Pendataan UMKM sebagai evaluasi peningkatan Usaha Mikro Kecil dan}

\section{Menengah Pada Kabupaten Sorong.}

Kegiatan pendataan ini dilakukan pada tanggal 11 Agustus 2018 berdasarkan data hasil survei sebelumnya dengan tujuan untuk mendata kemampuan usaha kecil sebagai acuan pelaksaan pendampingan usaha yang dilakukan sebagai upaya meningkatkan usaha menjadi lebih besar dan sehat di dalam menjalankan usaha.
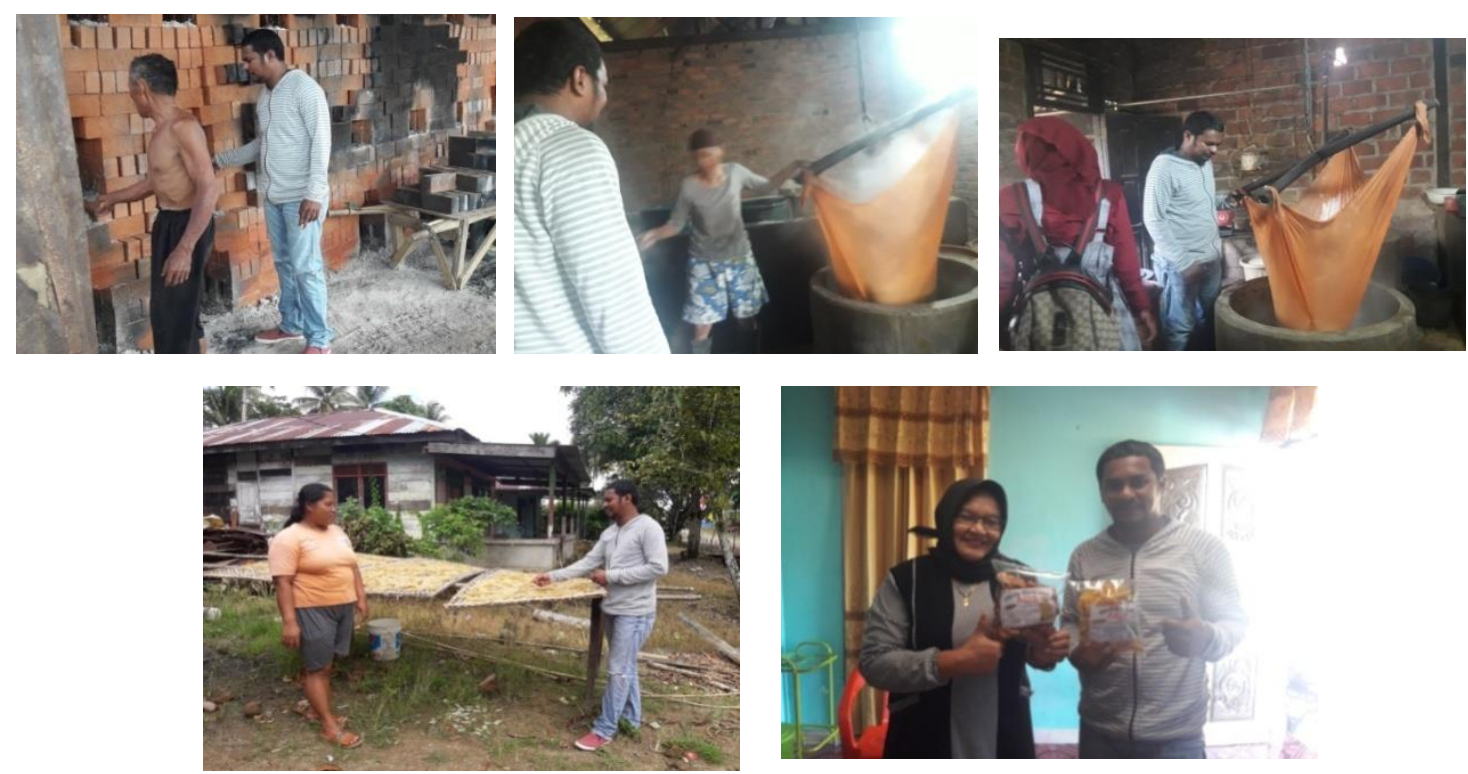

Gambar 3. Pendataan UMKM sebagai evaluasi peningkatan Usaha Mikro Kecil dan Menengah Pada Kabupaten Sorong.

Usaha Kecil yang dilakukan seperti Pengelolahan Tahu Tempe, Krupuk, dan Kripik dan percetakan batu bata yang di survei membutuhkan Pendampingan lanjutan 
sebagai upaya meningkatkna jumlah penjualan dan produksi serta pemanfaatan sektor Pendanaan Usaha dalam mengembangkan Usaha kecil.

\section{Bimbingan Teknis (BIMTEK) Peningkatan Produktifitas}

Kegiatan bimbingan teknis yang dilakukan terkait dengan topik pembiayaan UMKM sebagai solusi dalam meningkatkan produktivitas UMKM di Kabupaten Sorong. Pelaksanaan kegiatan ini dicetus oleh Pengelola Dan Konsultan PLUT - KUMKM Kabupaten Sorong.

\section{a. BIMTEK Peningkatan Produktivitas yang dilaksanakan pada UKM di}

\section{Jalan Mangga, Kelurahan Malawei - Distrik Aimas}

Kegiatan BIMTEK Peningkatan Produktivitas yang dilaksanakan pada UKM di Jalan Mangga, Kelurahan Malawei - Distrik Aimas dilaksanakan pada tanggal 17 September 2018. Peserta dari kegiatan ini adalah pelaku UKM 20 Orang, Pengelola Dan Konsultan PLUT - KUMKM Kabupaten Sorong.
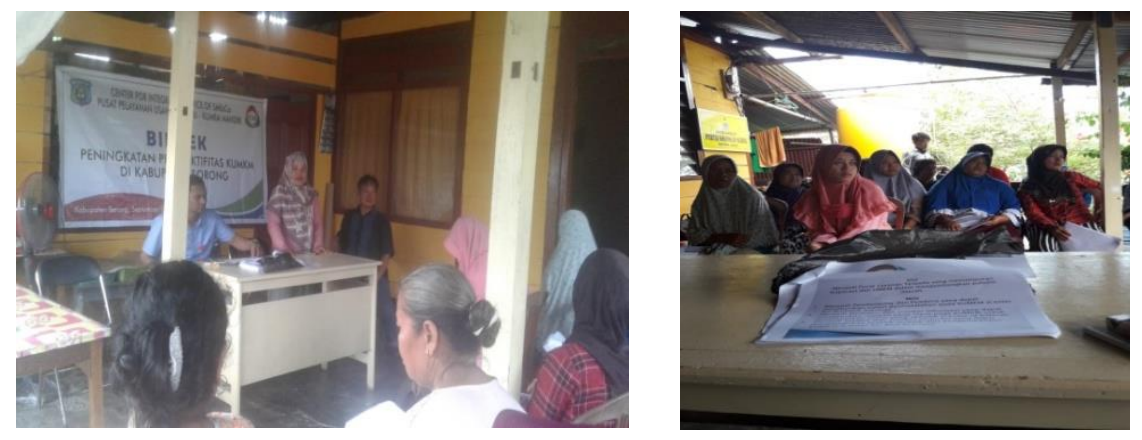

Gambar 4. Kegiatan BIMTEK Peningkatan Produktivitas yang dilaksanakan pada UKM di Jalan Mangga, Kelurahan Malawei-Distrik Aimas

b. BIMTEK Peningkatan Produktivitas yang dilaksanakan pada UKM di Kantor PLUT - KUMKM Mandiri Kabupaten Sorong, Jalan Pemakaman Baru Kantor Dinas Bupati Km 24 Klamono.

Kegiatan BIMTEK Peningkatan Produktivitas yang dilaksanakan pada UKM di Kantor PLUT - KUMKM Mandiri Kabupaten Sorong, Jalan Pemakaman Baru Kantor Dinas Bupati Km 24 Klamono. dilaksanakan pada tanggal 20 September 2018. Peserta dari kegiatan ini adalah pelaku UKM 20 Orang, Pengelola Dan Konsultan PLUT - KUMKM Kabupaten Sorong dan perwakilan mahasiswa Fakultas Ekonomi Dan Bisnis Manajemen Universitas Victory Sorong. 

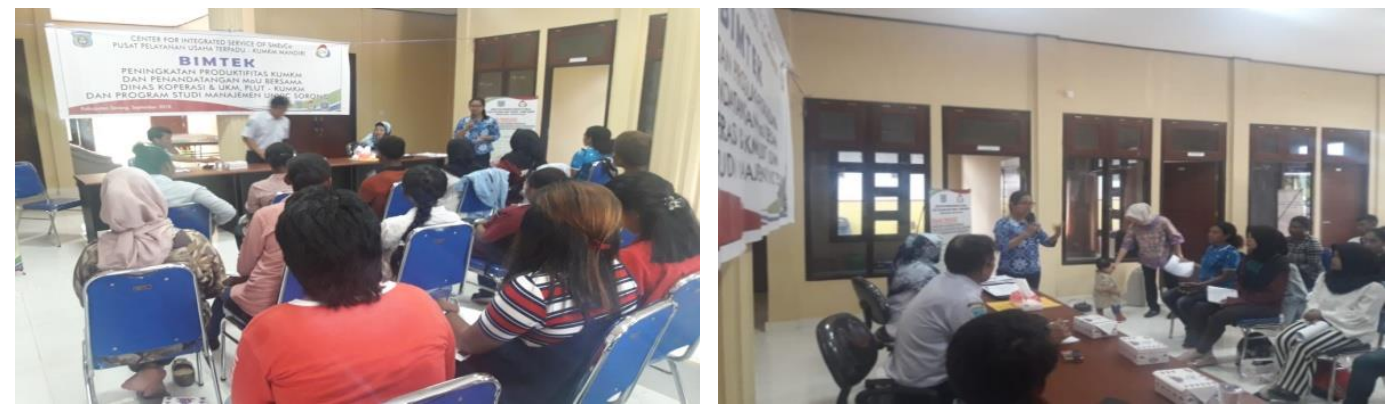

Gambar 5. Kegiatan BIMTEK Peningkatan Produktivitas yang dilaksanakan pada UKM di Kantor PLUT - KUMKM Mandiri Kabupaten Sorong

\section{c. BIMTEK Peningkatan Produktivitas yang dilaksanakan pada UKM di}

\section{Jalan Wortel Malewele - Distrik Aimas}

Kegiatan BIMTEK Peningkatan Produktivitas yang dilaksanakan pada UKM di Jalan Wortel Malewele - Distrik Aimas dilaksanakan pada tanggal 27 September 2018. Peserta dari kegiatan ini adalah pelaku UKM 20 Orang, Pengelola Dan Konsultan PLUT - KUMKM Kabupaten Sorong.
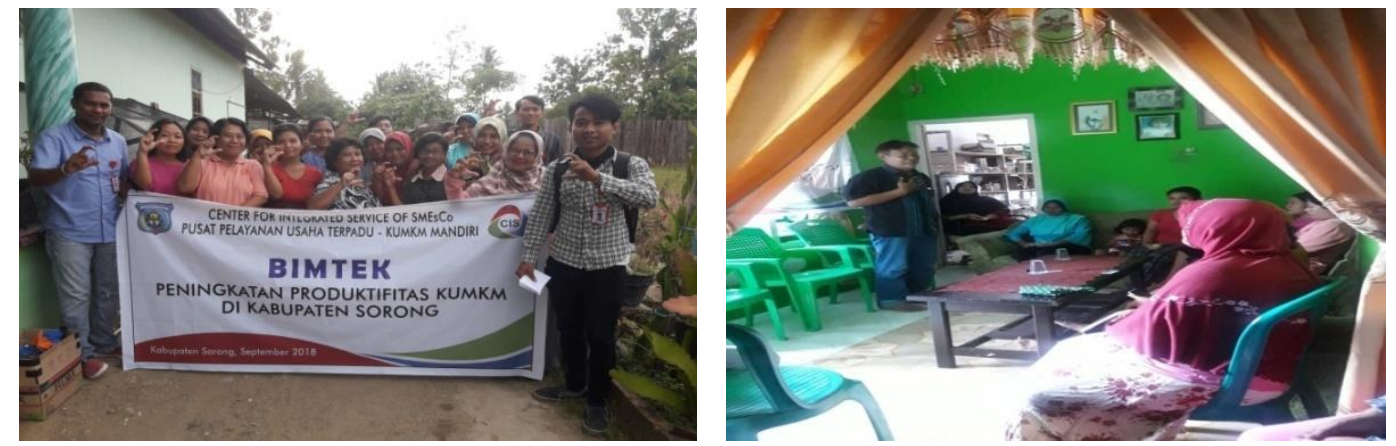

Gambar 6. Kegiatan BIMTEK Peningkatan Produktivitas yang dilaksanakan pada UKM di di Jalan Wortel Malewele - Distrik Aimas

Melaksanakan pembinaan Bimbingan Teknis dalam mempersiapkan UKM untuk lebih memaksimalkan Produktifitas kegiatan UKM dengan memanfaatkan peluang fasilitas kredit bank, bantuan koperasi, dan pihak ke 3 penyedia dana dalam membantu mengembangkan UKM lebih meningkat serta memaksimalkan Kredit Usaha Kecil yang merupakan solusi dalam permasalahan pembiayaan UKM untuk lebih berkembang dan Maju. Merespon persolaan UKM dalam mempersiapkan perencanaan bisnis jangka pendek, penyusunan proposal pengembagan usaha serta fasilitas dan mediasi akses ke lembaga keuangan dan berbagai sumber pembiyaan 
serta manajemen keuangan yang dilakukan bersama pelaku UKM pada saat pembimbingan teknis ini berjalan setiap saat.

\section{KESIMPULAN}

Usaha Mikro, kecil dan menengah (UMKM) adalah salah satu bidang yang memberikan kontribusi yang segnifikan dalam memacu pertumbuhan ekonomi Indonesia seperti penyerapan tenaga kerja, pemerataan distribusi hasil-hasil pembangunan, penanggulangan kemiskinan, dan lain sebagainya. Akan tetapi, permasalahan yang dihadapi UMKM cukup kompleks yaitu masih rendahnya produktivitas UMKM yang diakibatkan karena rendahnya kualitas sumber daya manusia UMKM khususnya dalam bidang manajemen, penguasaan teknologi, dan pemasaran. Selain itu, UMKM juga diperhadapkan pada terbatasnya akses kepada sumberdaya produktif, terutama terhadap permodalan, teknologi, informasi dan pasar. Permodalan merupakan faktor utama yang diperlukan untuk mengembangkan suatu unit usaha. Kurangnya permodalan UMKM, oleh karena pada umumnya usaha kecil dan menengah merupakan usaha perorangan atau perusahaan yang sifatnya tertutup, yang mengandalkan pada modal dari pemilik yang jumlahnya sangat terbatas, sedangkan modal pinjaman dari bank atau lembaga keuangan lainnya sulit diperoleh, karena persyaratan secara administratif dan teknis yang diminta oleh bank tidak dapat dipenuhi.

Kegiatan pengabdian masyarakat yang dilakukan untuk meningkatkan kesadaran para UMKM terkait dengan masalah pembiayaan dan memaksimalkan Produktifitas kegiatan UMKM dengan memanfaatkan peluang fasilitas kredit bank, bantuan koperasi, dan pihak ke 3 penyedia dana dalam membantu mengembangkan UMKM lebih meningkat serta memaksimalkan Kredit Usaha Kecil yang merupakan solusi dalam permasalahan pembiayaan UMKM untuk lebih berkembang dan Maju. Merespon persolaan UMKM dalam mempersiapkan perencanaan bisnis jangka pendek, penyusunan proposal pengembagan usaha serta fasilitas dan mediasi akses ke lembaga keuangan dan berbagai sumber pembiyaan serta manajemen keuangan yang dilakukan bersama pelaku UMKM pada saat pembimbingan teknis ini berjalan setiap saat. 


\section{DAFTAR PUSTAKA}

Anggraeni Feni Dwi Anggraeni, Imam Hardjanto, Dan Ainul Hayat. Pengembangan Usaha Mikro, Kecil, Dan Menengah (UMKM) Melalui Fasilitasi Pihak Eksternal Dan Potensi Internal (Studi Kasus Pada Kelompok Usaha “Emping Jagung” Di Kelurahan Pandanwangi Kecamatan Blimbing, Kota Malang) Jurnal Administrasi Publik (JAP), Vol. 1, No. 6, Hal. 1286-1295

Jauhari Jaidan.(2010). Upaya Pengembangan Usaha Kecil Dan Menengah (Ukm) Dengan Memanfaatkan E-Commerce. Jurnal Sistem Informasi (JSI), VOL. 2, NO. 1, April 2010. Halaman 159-168

Layyinaturrobaniyah \& Wa Ode Zusnita Muizu (2017). Pendampingan Pengelolaan

Keuangan Usaha Mikro Di Desa Purwadadi Barat Dan Pasirbungur Kabupaten Subang. Pekbis Jurnal, Vol.9, No.2, Juli 2017 : 91-103

Wahyuningsih Sri.(2009). Peranan Ukm Dalam Perekonomian Indonesia. Jurnal Ilmu-ilmu Pertani VOL 5. NO 1, 2009

Undang-undang Nomor 20 Tahun 2008 tentang Usaha Mikro, Kecil, dan Menengah. 